液 相 空 気 酸 化

\section{增尾宫士 雄*}

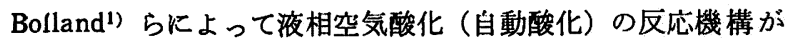
提案されてから，すでに 15 年の歳月が経ち，この間多くの著名 な化学者によってこの問題が取り上げられ，反応速度論的ならび に有機化学的な立場から研究が進められ，括およその大系が打ち 立てられた。またこの反応を利用したクメン法石炭酸合成法2)や アルコールの酸化による過酸化水素の製造法息などが工業的に実 施されるに至った。また液相空気酸化と密接な関保を持つ酸化防 止剤の研究も, より精度の高い動力学的測定々有機化学的研究に より，その作用機構が明らかにされ，より有効な酸化防止剤が追 求されている。自動酸化はその名の上5に, 自然に空気中の酸素 によって起る反応であるから、ゴムの酸化ゼイ化住はもちろんの こと, 天然拉よび合成高分子の酸化ゼイ化の機構を明らかにする とともに，高分子の酸化を第一段階とするグラフト重合5) の研究 も活発に行なわれている。自動酸化反応恃典型的なラジカル反応 であるから，ラジカルの反応性を研究する手段として合目的的で あり, 得られた知識は広く利用され，最近の放射線化学の一つの 根底となるるのであると考兄られる。

本稿に执いては, 自動酸化を適当な開始剤を用いて, 利用し得 る速度とした液相空気酸化，とくに比較的低温 $\left(100^{\circ} \mathrm{C}\right.$ 前後) の 空気酸化を取扱 5 ものであるが，高温液相酸化も低温空気酸化と 同じような経過をたどり行なわれるるのと考えられている6)。た だ，高温液相酸化に批いては生成したヒドロペルオキシド (HP) の熱分解によって生成物が複雅となることと, 高温では酸素の溶 解度が減少するため反応型式が変わり, ラジカルがイマーが生成 しやすい?)。液相酸化は被酸化物の濃度が高いこと, “Cage” 効果 のためラジカルの拡散が扰そく器壁での連敛停止が起り難いこ と, 生成したヒドロペルオキシドの熱分解および器壁での接触分 解がすくないことなどの理由で, 気相酸化より有利であり, 反応 の選択性も良好である。研究方法る気相法にくらべ簡単であり, 連鎖開始も適当な開始剤, 開始力法を選択して用いることができ る。酸化反応の動力学的迎跡は恒生の酸素吸収量測定汇上って行 ならのが便利であり, 湘定装置泪風しては別に報告した8)。酸化 方法に乳化重合法と同じように, 被酸化物を水中に乳化分散させ て酸化する方法があり, Armstrong, Hall，Quin の報告9があ り，特許にもなり，クメン法の重要な一う法となっている。乳化 酸化法は, 酸化表面を增人し, 溶解酸素量を增し, 反応速度を增 大するととるに，反応熱を除尘して反心速度を調節する。また水 溶性分解生成物を反汒系より除去し, 反沁の自己抑制作用を低减 し, 樹脂状酸化生成物の生成を抑制する。

とにかく，液相空父酸化は，空気中の酸素を陖化剂として有機 化合物を酸化し，特定の陵化特成物を合成する才法であり，経济的

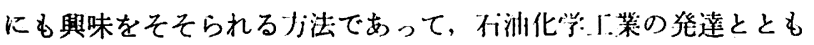
に今後ますます重要性を增するのと考えられる。次化，液相空気 酸化の動力学的研究を概説しこれと関速して酸化抑制剂(禁止剤)

*京都工芸織維大学: 京都门左察区松ヶ略.
について述へ，最後にアルコールの液相空気酸化に触れることに する。アルデヒドの酸化は古くから研究があり, アセトアルデヒ ドの夜相酸化は酢酸の製造法として現在す用いられている。最近 アセトアルデヒドの低温液相酸化により酢酸生成の中間体過酢 酸ーアセトアルデヒドの付加化合物を分け，分解してアセトアル デヒドを除き過酸酸を製造する方法 ${ }^{10}$ が発表され，過醀酸の利用 ととるに注目されている。

\section{1 液相空気酸化反応}

液相空気酸化が連鎖反応があり，次の Bolland-Gee の反応形 式化したがうことは一般に認められている。

連鎖開始

$$
\mathrm{RH}+\mathrm{X} \stackrel{\boldsymbol{R}_{i}}{\longrightarrow} \mathrm{R} \cdot+\mathrm{XH}
$$

連 鎖 環

$$
\begin{aligned}
& \mathrm{R} \cdot+\mathrm{O}_{2} \stackrel{k_{2}}{\longrightarrow} \mathrm{ROO} \cdot \\
& \mathrm{ROO} \cdot+\mathrm{RH} \stackrel{k_{3}}{\longrightarrow} \mathrm{ROOH}+\mathrm{R} .
\end{aligned}
$$

連鎖停止

$$
\begin{aligned}
& \mathrm{R} \cdot+\mathrm{R} \cdot \stackrel{k_{4}}{\longrightarrow} \mathrm{R}-\mathrm{R} \quad(\text { または不均化反応 })^{11)} \\
& \mathrm{R} \cdot+\mathrm{ROO} \cdot \stackrel{k_{5}}{\longrightarrow} \mathrm{ROOR}(\text { または不均化反応 }) \\
& \mathrm{ROO} \cdot+\mathrm{ROO} \cdot \stackrel{k_{s}}{\longrightarrow} \mathrm{ROOR}+\mathrm{O}_{2} \\
& \quad(\text { または不均化反応 })
\end{aligned}
$$

連鎖開始反応の速度を $R_{i}$ として, $k_{5}{ }^{2}=k_{4} k_{6}$ を仮定して定常状 態法により, $\mathrm{d}[\mathrm{R} \cdot] / \mathrm{d} t=0, \mathrm{~d}[\mathrm{ROO} \cdot] / \mathrm{d} t=0$ よりこれらの式を解 き，微小頂の省略を行なって，酸素の吸収速度は（1）式で表わ される。

$$
R=R_{i}^{1 / 2} \frac{k_{2} k_{3}\left[\mathrm{O}_{2}\right][\mathrm{RH}]}{k_{2} k_{6}{ }^{1 / 2}\left[\mathrm{O}_{2}\right]+k_{3} k_{4}^{1 / 2}[\mathrm{RH}]}
$$

酸素王の高い場合

$$
R_{\mathrm{H}}=R_{i} i_{6_{6} / 2}^{\underset{k_{8}}{2}[\mathrm{RH}]}
$$

酸素此の低い場合は，

$$
R_{\mathrm{L}}=R_{i}^{1 / 2} \stackrel{k_{2}\left[\mathrm{O}_{2}\right]}{k_{4}{ }^{1 / 2}}
$$

（2），(3）式はまたそれぞれ（1-1) (1-2) (1-3) (1-6)，(1-1) (1-2) (1-3) (1-4) の組合わせにより定常状態法汇よって簡単佂水 められる。Bateman ら ${ }^{12)}$ は (1-1) 〜 (1-6) 式から，連鎖長が 一 分に舆いとい5仮定と $\mathrm{d}[\mathrm{R} \cdot] / \mathrm{d} t+\mathrm{d}[\mathrm{ROO} \cdot] / \mathrm{d} t=0$ とから, 次の 両式を得，

$$
\begin{gathered}
k_{2}[\mathrm{R} \cdot]\left[\mathrm{O}_{2}\right]=k_{3}[\mathrm{ROO} \cdot][\mathrm{RH}] \\
R_{i}-k_{4}[\mathrm{R} \cdot]^{2}-2 k_{5}[\mathrm{R} \cdot][\mathrm{ROO} \cdot]-k_{6}[\mathrm{ROO} \cdot]^{2}=0
\end{gathered}
$$

この両式から $[R \cdot]$ または $[R O O \cdot]$ を消尘して次の式に代入し

て酸化速度として (4) 式を得た。

$$
\begin{aligned}
R & =k_{2}[\mathrm{R} \cdot]\left[\mathrm{O}_{2}\right]=k_{3}[\mathrm{ROO} \cdot][\mathrm{RH}] \\
& =R_{\mathrm{H}}\left\{1+2 \phi A^{-1} B[\mathrm{RH}]\left[\mathrm{O}_{2}\right]^{-1}+A^{-2} B^{2}[\mathrm{RH}]^{2}\left[\mathrm{O}_{2}\right]^{-2}\right\}^{-1 / 2}
\end{aligned}
$$


ここで

$$
\left.\begin{array}{l}
A=k_{2} k_{4}{ }^{1 / 2} \\
B=k_{3} k_{6}{ }^{-1 / 2} \\
\phi=k_{4}^{-1 / 2} k_{5} k_{6} \cdot 1 / 2 \\
R_{\mathrm{H}}=B[\mathrm{RH}] R_{i}^{1 / 2}
\end{array}\right\}
$$

である。酸素圧の高い場合は， $R=R_{\mathrm{H}}$ となり，（2）式と一致す る。 $\phi=1$ のときは，

$$
R=R_{\mathrm{H}}\left\{1+A^{-1} B[\mathrm{RH}]\left[\mathrm{O}_{2}\right]^{-1}\right\}^{-1}
$$

となり，(1) 式となる。

(6) 式から $1 / R$ と $1 /\left[\mathrm{O}_{2}\right]$ は直線哭係にあり, 傾斜と初片と から $A^{-1} B$ が求められ, $R_{\mathrm{H}}=B[\mathrm{RH}] R_{i}^{1 / 2}$ から $B$ を求めて,

$A ， B$ を求めることができる。

$\phi$ は反応性の大きい化合物ほど大き? , 反応性の小なるものは 小さいので, $\phi=1\left(k_{5}{ }^{2}=k_{4} k_{6}\right)$ の仮定は厳密にはあてはまらない。 (4) 式から

$\left[\left(R_{\mathrm{H}} / R\right)^{2}-1\right]\left[\mathrm{O}_{2}\right]=2 \phi A^{-1} B[\mathrm{RH}]+A^{-2} B^{2}[\mathrm{RH}]^{2}\left[\mathrm{O}_{2}\right]^{-1}$

が得られるから， $\left[\left(R_{\mathrm{H}} / R\right)^{2}-1\right]\left[\mathrm{O}_{2}\right]$ と $1 /\left[\mathrm{O}_{2}\right]$ をグラフに描き， $\phi A^{-1} B, A^{-2} B^{2}$ が求められ， $R_{\mathrm{H}}, B$ を求めることにより $\phi, A$, $B$ を $k_{5}^{2}=k_{4} k_{6}$ の仮定なしに求めることができる。

普通の自動酸化反応では, 酸素圧の高い場合に相当し, (2)式 が広く適用される。

（2）式は酸化の速度が, 開始反応速度の $1 / 2$ 乗, 被酸化物の 濃度の 1 乗に比例し，酸素圧に無関係であることを示し，酸化反 応がこの式に適合するかどうかは，これらを確かめることによっ て判定することができる。普通 100 200 $\mathrm{mmHg}$ 以上の酸素珐で 適用できるが，この範团の圧力でも（2）式が適合せず，（1)式 を用いねばならない場合がある ${ }^{19)}$ 。(2) 式の比例定数 $k_{3} / k_{6}{ }^{1 / 2}$ の $k_{3}$ はペルオキシラジカルによる被酸化物の水素引き抜き反応 （1-3）の速度定数であって, 酸化速度を大きく支配し, 被酸化物 の構造によって変化する。また酸化反沁速度の温度勾配から $E_{\mathrm{s}}$ $-1 / 2 E_{6}$ が求められ， $E_{6}$ はラジカルどうしの反応の活性化エネ ルギーであり，零と考えると(1-3) 反応の活性化エネルギーが求 められる。 $E_{3}$ と被酸化物の反応性関しては, 高橋 ${ }^{14)}$, 筆者 ${ }^{15)}$ らの総説がある。

酸化反応の鎖長はまた酸化速度を支配するものであるが，鎖舆 は酸化速度を連銷開始速度 $R_{i}$ で制ることによって（8）式であ たえられる。

$$
l=\frac{R_{\mathrm{H}}}{R_{i}}=\underset{R_{i}^{1 / 2}}{1} \cdots k_{k_{6}{ }^{1 / 2}}^{k_{3}}[\mathrm{RH}]
$$

クメンは酸化速度が大きく工業的に垁施されているが， $k_{3}$ は 人きくないが $k_{6}$ が小さく，鎖長が長いことになる（表 1 参照） 連鎖の寿命 (life time) を $\tau$ とすれば， $\tau$ は物成した ROO・ラ ジカルが連鎖をくり返して消失するまでの㸟閒であるから，定漟 状態では

$$
\tau=\begin{gathered}
\mathrm{ROO} \text { ・ ラジカルの濃位: } \\
\mathrm{ROO} ・ \text { ラジカルの消失速度 }
\end{gathered}=\begin{gathered}
{[\mathrm{ROO} \cdot]} \\
k_{6}[\mathrm{ROO} \cdot]^{2}
\end{gathered}=\begin{gathered}
1 \\
k_{6}[\mathrm{ROO} \cdot]
\end{gathered}
$$

となる。また定常状態では $R_{i}=k_{6}[\mathrm{ROO} \cdot]$ であるから，[ROO・]

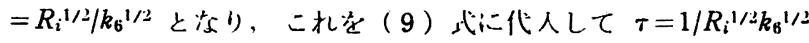

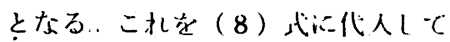

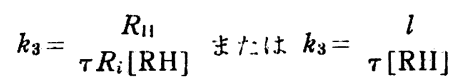

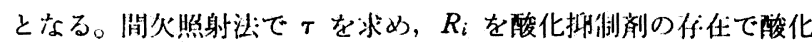

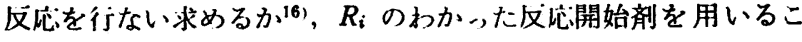
とにより(10)式より $k_{3}$ が，したがって $k_{6}$ が求められる。 $k_{3}, k_{6}$ はこのほか，反応途中光を遮断または照射して起る Batemann, $\mathrm{Gee}^{17}$ ) の光化学的前効果または後効果 (photochemical pre- or after effect) を利用して $k_{3} / k_{6}$ を求め， $k_{3} k_{6}{ }^{1 / 2}$ とから $k_{3}, k_{6}$ を 求める方法がある。下村はこの方法を用いて $n$-ブチルアルデヒ ド酸化の $k_{3}, k_{6}$ を求めた ${ }^{18)}$ 。

各種の連鎖開始反応その他についてはすでに総説した7)。

最近高分子溶液の空気酸化は，グラフト重合と関係して注目を 浴びているが，原則的に一般の液相酸化の反応式が適用できる。 しかし高分子の特性にしたがって反応性は異なり, たとえば粘度 の上䄯とともに，連鎖長が短かくなってくる。高分子の空気酸化 は, 現在までに得られた低分子での実験をモデルとして進めるべ き重要な研究課題である。

\section{2 酸化抑制剂（酸化防止剂）}

何らかの方法で連鎖開始反応を行なった液相空気酸化反応で は, 開始反応の速度と $k_{3}, k_{6}$ の大きさによって, 酸化速度が支 配される。いいかえると開始反応速度と連鎖生長反応に扣ける水 素引き抜きの速度と連鎖長とが酸化反応速度を支配するものであ る。

開始反応に過酸化ベンゾイル (BPO), アゾビスイソブチロ= トリル (AIBN)，クメンヒドロペルオキシド(CHP)を用いた場 合は, それぞれの自己分解速度 $\left(k_{1}\right)$ の $1 / 2$ 乗に比例する速さで 連鎖が開始される。

$$
\begin{aligned}
\text { BPO }: & k_{1}=3.0 \times 10^{19} e^{-29,660 / R T^{19)}} \\
\text { AIBN }: & k_{1}=1.0 \times 10^{15} e^{-30,700} / R T^{19)} . \\
\text { CHP }: & k_{1}=2.7 \times 10^{12} e^{-30,400} / R T^{20)}
\end{aligned}
$$

\begin{tabular}{|c|c|c|c|c|c|c|c|c|}
\hline \multicolumn{6}{|c|}{ 表 } & \multicolumn{3}{|c|}{1} \\
\hline 化 & î́ & 物 & & $\begin{array}{l}\text { 溜 度 } \\
\left({ }^{\circ} \mathrm{C}\right)\end{array}$ & $\begin{array}{c}k_{3} \\
(l / \mathrm{mol} \\
\text { sec })\end{array}$ & $\begin{array}{c}k_{6} \times 10^{-0} \\
\left(l / \mathrm{mol}^{-}\right. \\
\text {sec })\end{array}$ & $\begin{array}{c}E_{3} \\
\text { (kcal/ } \\
\text { mol) }\end{array}$ & $\begin{array}{c}E_{\mathrm{B}} \\
(\mathbf{k c a l} / \\
\text { mol })\end{array}$ \\
\hline \multirow[t]{2}{*}{ テ } & F & y & ע & 25 & 13.3 & 21.5 & 4.5 & 0.4 \\
\hline & " & & & 45 & 20.87 & 22.4 & $"$ & $"$ \\
\hline \multirow[t]{2}{*}{$\eta$} & $x$ & & ン & 50 & 0.31 & 0.028 & 6.7 & - \\
\hline & " & & & 65 & 0.56 & 0.033 & " & - \\
\hline シクロ & へキ & $\neq t$ & ע & 15 & 0.65 & 0.95 & $9 . \overline{5}$ & 2 \\
\hline 1 イチル & レシク & D & キセン & " & 1.1 & 0.5 & $8 . \bar{j}$ & 2 \\
\hline \multirow[t]{2}{*}{ ע) } & ル酸 & × & $=\pi$ & 15 & 5.7 & 0.5 & 7.0 & 2 \\
\hline & " & & & 20 & 50 & 20 & $"$ & " \\
\hline \multirow{3}{*}{$\begin{array}{l}\text { オ } \\
n-フ ゙\end{array}$} & テ & : & -1 & 25 & 0.03 & 0.3 & 7.3 & - \\
\hline & + & - & ル & -10 & 450 & 1.8 & - & - \\
\hline & " & & & -20 & 350 & 2.3 & $\cdots$ & - \\
\hline$n$-オ ク & タナ & $1-$ & ル & 5 & 720 & 7.5 & 4.2 & 1 \\
\hline ペンズ & $T M$ & デヒ & : & 5 & 1910 & 210 & 1.8 & 1 \\
\hline
\end{tabular}

光增感反応が開始反応として用いられる場合は, 連鎖開始速度 は光量の $1 / 2$ 乗に比例し, 他の要素に支配されることなく, 時間 に無関係に一定である。

$k_{3}, k_{6}$, 対応する活性化エネルギー $E_{3} ， E_{6}$ を表 1 に示した。

表 1 の値を（8）式に代入して鎖長を概算すれば，テトラリン, クハンでは数百の値となる。

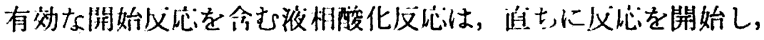
初期に打いてて怕線似に進行与るから初速度解析法によって容易

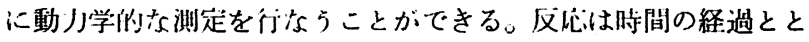
もに低卜する。開始凨濃度の低卜，被酸化物の濃度低卜による反 他速度の低下のほか，反淀生成物による連鎖停止に上り鎖長が短 かくなることが人きく影算する。この自己酸化抑制作用は，反応 
生成物によって異なってくるので，この問題は不純物の影響，と くに酸化抑制剤（酸化防止剤）の方面から別個に進められてい る。

璉続移動を起しや寸いフェノール類，アミン類、アルコール類 などが研究の中心となって扣り，抑制酸化は，酸化反心動力学 的研究の手段としても，また扶用的な面でも重要な問題である。

まず Bolland, ten Have ${ }^{21)}$ は,フェノールを㧕制剤（Retarder)として用い, 抑制酸化速度 $R_{r}$ と抑制剤を加えない酸化速度 $R$ (1 式) とを組合せて酸化抑制剂の効率を求めた。抑制剂 $(\mathrm{PH})$ は連鎖担体ラジカルと反応して連鎖を停止する。酸素圧の高い場 合は,

$$
\mathrm{ROO} \cdot+\mathrm{PH} \stackrel{k_{7}}{\longrightarrow} \mathrm{ROOH}+\mathrm{P} \cdot
$$

(1-1)，(1-2)，(1-3)，(1-7) から定常状態法により，式を解 き，(11）式を得，抑制剤の濃度を適当に選ぶことにより連鎖は な怙十分に長いと考えて，(11）式が得られる。

$$
\begin{aligned}
& R_{r}=R_{i}\left(1+\frac{k_{3}[\mathrm{RH}]}{k_{7}[\mathrm{PH}]}\right) \\
& R_{r}=R_{i} \frac{k_{3}[\mathrm{RH}]}{k_{7}[\mathrm{PH}]}
\end{aligned}
$$

(2) 式と組合せて,

$$
R_{r}=\frac{k_{6}}{k_{s} k_{7}} \quad\left[\begin{array}{cc}
R_{\mathrm{H}^{2}}^{2} \\
{[\mathrm{RH}][\mathrm{PH}]}
\end{array}\right.
$$

$k_{7}$ は酸化抑制剤と連鎖担体ラジカルとの反纫性を示す定数でせ $\eta ， k_{3} ， k_{6}$ は被酸化物によって‥定であるから，条種の酸化抑制 剤について $k_{6} / k_{3} k_{7}$ を求め，この逆数を抑制剂の比効獄と考える ことができる。また $k_{3}[\mathrm{RH}] / k_{7}[\mathrm{PH}]$ は抑制酸化の連鎖長をむた える。ヒドロキノンでは $k_{7} / k_{3}$ は 1200〜1800 の佰が得られてい $ろ^{22)}$ 。

Cooper, Melville ${ }^{16)}$ は, ヒドロキノン $\left(\mathrm{H}_{2} \mathrm{q}\right)$ を抑制剂として 次式から， 1 分子の $\mathrm{H}_{2} \mathrm{q}$ が 2 個の ROO・を消費すると考えると， $\mathrm{ROO} \cdot+\mathrm{H}_{2} \mathrm{q} \longrightarrow \mathrm{ROOH}+\mathrm{Hq} \cdot$

$2 \mathrm{Hq} \cdot \longrightarrow \mathrm{H}_{2} \mathrm{q}+\mathrm{q}$

ヒドロキノンの減少速度は（13）式で示されう。

$$
-\frac{\mathrm{d}\left[\mathrm{H}_{2} \mathrm{q}\right]}{\mathrm{d} t}=\frac{R_{i}}{2}
$$

$t=0$ のとき $\left[\mathrm{H}_{2} \mathrm{q}\right]=\left[\mathrm{H}_{2} \mathrm{q}\right]_{0}$ とい5 条件を入れて積分すると

$$
\left[\mathrm{H}_{2} \mathrm{q}\right]=\left[\mathrm{H}_{2} \mathrm{q}\right]_{0}-\frac{1}{2} R_{i}
$$

（14）式を(11)' 式に代入して

$$
R_{r}=\begin{gathered}
k_{3}[\mathrm{RH}] R_{i} \\
k_{7}\left[\mathrm{H}_{2} \mathrm{q}\right]_{0}-1 / 2 k_{7} R_{i} t
\end{gathered}
$$

（15）式を書き换えて

$$
\frac{1}{R_{r}}=\begin{gathered}
k_{7}\left[\mathrm{H}_{2} \mathrm{q}\right]_{0} \\
k_{3}[\mathrm{RH}]
\end{gathered} \cdot \frac{1}{R_{i}}-\underset{2 k_{3}[\mathrm{RH}]}{k_{7}} \cdot t
$$

$1 / R_{r}$ と晾間 $t$ とをブロットすれば直線となり，その倾斜と $1 / R_{r}$ 軸との交点の比から，(17）式で $R_{i}$ を求めた。

$$
\begin{gathered}
\text { 傾斜 } \\
\text { 交点 }
\end{gathered}=\begin{gathered}
k_{7} \\
k_{3}[\mathrm{RH}]
\end{gathered} / \begin{gathered}
k_{7}\left[\mathrm{H}_{2} \mathrm{q}\right]_{0} \\
2 k_{3}[\mathrm{RH}] R_{i}
\end{gathered}=\begin{gathered}
R_{i} \\
2\left[\mathrm{H}_{2} \mathrm{q}\right]_{0}
\end{gathered}
$$

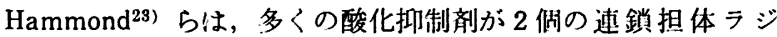
カルを安定化し，POOR に相当する化合物を生成することから （1-7）式の代わりに (1-8) 式を立て,

$$
2 \mathrm{ROO}+\mathrm{PH} \stackrel{k_{8}}{\longrightarrow} \mathrm{ROOH}+\mathrm{POOR}
$$

$R_{i}=R_{t}$ (停忖速度) から，ラジカル開始剂を用いた場介
$2 a k_{1}[$ Initiator $]=2 k_{8}[\mathrm{ROO} \cdot]^{2}[\mathrm{PH}] \quad(a=$ 連鎖開始効率 $)$ となり，（18）式を得た。

$$
R_{r}=k_{3}[\mathrm{RH}][\mathrm{ROO} \cdot]=k_{3}[\mathrm{RH}]\left\{\frac{a k_{1}[\text { Initiator }]}{k_{8}[\mathrm{PH}]}\right\}^{1 / 2}
$$

闹・の開始剂を用い，抑制剂を変化して $R_{r}$ を求め，(19) 式に

$$
\begin{aligned}
& k_{8} \\
& k_{3_{0}}
\end{aligned}=\left(\begin{array}{c}
R_{r_{0}} \\
R_{r}
\end{array}\right)^{2}
$$

よって比効率を求めた。

強力な酸化防止剤（たとえば 2,6-tert-ブチルーpークレゾール （I ））では $10^{-4} \mathrm{~mol} / l$ 程度の添加量です反応は完全に停止し， 禁止剤 (Inhibitor, InH) として働く。この場合は酸素の吸収が 全然起らないか, 起っても極くわずかであるから前述のような抑 制酸化法によって比効率を求めることはできない。禁止期が終る と直ちに酸化を開始し正常な速度で進行するから，この場合は禁 止期の長さで酸化防止効果を判定する。禁止期 $(t)$ は，次の $(20)$ 式で表わされる。

$$
t=n[\operatorname{InH}] / 2 a k_{1} \text { [Initiator] }
$$

$$
n \text { は InH } 1 \text { 分子が消費するラジカルの数 }
$$

筆者らは ${ }^{24)}$ ，AIBN を開始剤としてクメンに I，II，III を $10^{-4}$ $\mathrm{mol} / l$ 稆度加えた奏験において，禁止期から， $n$ を求め， $\mathrm{I}=2$, $\mathrm{II}=4$, III $=6$ に近い值を得た。

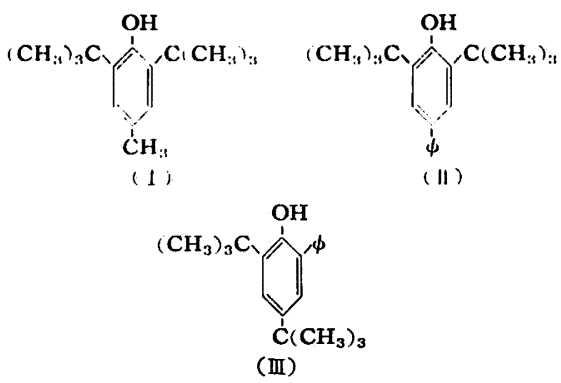

クメンに対して（Ｉ）は禁止剤であり，明暸な禁止期を示して， 酸化防止剤が消滅するまで酸化反応は進行しない。フェノールは 抑制剂として働き，禁!期を示さず，反応は徐々であるが次第に

$$
R_{r}=R_{i}+R_{i}{ }_{k_{7}}^{k_{3}[\mathrm{RH}]}
$$

加速される。(11) 式において， $k_{7}[\mathrm{PH}]>k_{3}[\mathrm{RH}]$ では連鎖反伈 とならず，反応速度は $R_{i} \sim 2 R_{i}$ の速さで進行し，禁止期間に $\mathrm{PH}$ は消隇して，急に立ち上り正常な酸化速度を示す。 $k_{3}[\mathrm{RH}]>k_{7}$ [PH] の場合は，初期から何回かの連鎖反応をくり返して，連鎖 長に相当した酸素を吸収し停小:に至る。PH の消失にしたがって 反応速度を增し，最後に $\mathrm{PH}$ が消隇して定常状態に達する。 $k_{7}$ がラジカルによる抑制剂からの水素引き报き反心汇より支配され るならば，酸化抑制剂の効新は被酸化物と酸化抑制剂との水素引 き拢き反心性の問題となる。ところが Hammond らは，Hの代 わりにDを入れても间位元素効果を亦さないこと，引き拔かれる Hを布しない化命物も强い抑制効榡を持つこと，効果が溶煤の種

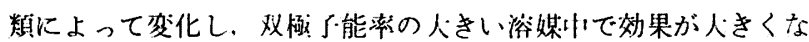
ること、効果はハィット剘にしたがい， $\rho=-3.7$ であることか ら、抑制剤と連敛担体ラジカルとの $\pi$ 電子結命分了·錯化命物を考 え, 次式で抑制剤の反応を示した。

$$
\begin{gathered}
2 \mathrm{ROO} \cdot+\mathrm{PH} \stackrel{K_{\mathrm{r}}}{\rightleftharpoons}[\mathrm{ROO} \cdot \leftarrow \mathrm{PH}]+\mathrm{ROO} \cdot \stackrel{k_{8}{ }^{\prime}}{\longrightarrow} \text { 脌:成物 } \\
k_{8}=K_{\mathrm{r}} \times k_{8}{ }^{\prime}
\end{gathered}
$$

Iのようなカサ高い基をオキシ基の両側に有する化令物が材郊 
な酸化防止剤となることをよく説明するものである。

Angert, Kuzminskii ${ }^{25)}$ は, ゴムの酸化防止機構について研究 したが，高分子中では酸化防止剤の拡散がおそいために，低分子 の炭化水素にくらべ有効率が低く50 100 倍の防止剤を添加する 必要があると述べている。

\section{3 アルコールの液相空気酸化}

アルコールが気相接触脱水素（酸化）反応によって，アルデヒ ドまたはヶトンと水素 (水)を生成することはよく知られている。 最近アルコールを液相空気酸化することにより，アルデヒドまた はケトンと過酸化水素を生成する反応が実用されるようになって きたが, アルコール類の液相空気酸化に関する研究は比較的すく ない。ます酸化の第 1 段階としてアルコールの水素引き抜きが起 るが，どの水素がとれやすいかについては Kharasch の有名な研 究があり，水酸基の $\alpha$-炭素の水素が引き抜きを受けることが明 らかにされた。C-H と O-H の平均結合エネルギーは，前者が $98.2 \mathrm{kcal} / \mathrm{mol}$, 後者が $109.4 \mathrm{kcal} / \mathrm{mol}$ であり, $\alpha \mathrm{C}-\mathrm{H}$ が切れ易<smiles>[R][C@H](O)[Y4]#CC([R])([R])O</smiles>

いことがわかる。アルコール類の水素引き抜き反応に関しては多 くの研究があり ${ }^{15)}$, 予想外に反応性の大きいものであることが示 された。パラフィン，オレフィン，アルコール，エーテルなどに ついて水素引き抜き反応性を表 2 に示した。

表 2 各䄲水素 1 個あたりの水素引き抜き速度定数

\begin{tabular}{lcccc} 
Hの種類 & パラフィン & オレフィン & アルコール & エーテル \\
\hline prim $\mathbf{H}$ & 0.3 & 5.0 & 2 & 1.5 \\
sec. $\mathbf{H}$ & 2.1 & 17 & 10 & - \\
tert. $\mathbf{H}$ & 15 & 53 & 31 & 19
\end{tabular}

筆者ら ${ }^{27}$ は, 各種アルコール中での BPO の分解反応を研究し, 次式にしたがうことを明らかにし， $k_{2}, k_{3}$ の相対値を求めた。

$$
\begin{aligned}
& (\phi \mathrm{COO})_{2} \stackrel{k_{1}}{\longrightarrow} 2 \phi \mathrm{COO} \cdot \\
& \phi \mathrm{COO} \cdot \stackrel{k_{1}{ }^{\prime}}{\longrightarrow} \phi \cdot+\mathrm{CO}_{2} \\
& \phi \mathrm{COO} \cdot+\mathrm{RR}^{\prime} \mathrm{CHOH} \stackrel{k_{2}}{\longrightarrow} \phi \mathrm{COOH}+\mathrm{RR}^{\prime} \dot{\mathrm{COH}} \\
& \phi \cdot+\mathrm{RR}^{\prime} \mathrm{CHOH} \stackrel{k_{2}{ }^{\prime}}{\longrightarrow} \phi \mathrm{H}+\mathrm{RR}^{\prime} \dot{\mathrm{COH}} \\
& \mathrm{RR}^{\prime} \dot{\mathrm{COH}}+(\phi \mathrm{COO})_{2} \stackrel{k_{3}}{\longrightarrow} \\
& \quad \phi \mathrm{COO} \cdot+\mathrm{RR}^{\prime} \mathrm{C}(\mathrm{CH}) \mathrm{OCO} \phi \\
& \mathrm{RR}^{\prime} \dot{\mathrm{COH}}+\phi \mathrm{COO} \cdot \stackrel{k_{4}}{\longrightarrow} \mathrm{RR}^{\prime} \mathrm{C}(\mathrm{OH}) \mathrm{OCO} \phi \\
& \mathrm{RR}^{\prime} \mathrm{C}(\mathrm{OH}) \mathrm{OCO} \phi \longrightarrow \mathrm{RR}^{\prime} \mathrm{C}=\mathrm{O}+\phi \mathrm{COOH}
\end{aligned}
$$

この系に常压の酸素が存在する場合は，(3-3) 式で示される誘 発分解は全く阻止され, 連鎖反応で酸化反応が起り, 当量のカル ボニル化合物と過酸化水素を生成する。反応式は，次の諸式で示 さ机る。

$$
\begin{aligned}
& (\phi \mathrm{COO})_{2} \stackrel{k_{1}}{\longrightarrow} 2 \phi \mathrm{COO} \cdot \\
& \phi \mathrm{COO} \cdot(\phi \cdot)+\mathrm{RR}^{\prime} \mathrm{CHOH} \stackrel{k_{2}}{\longrightarrow} \\
& \mathrm{RR}^{\prime} \mathrm{COH}+\phi \mathrm{COOH}(\phi \mathrm{H}) \\
& \mathrm{RR}^{\prime} \dot{\mathrm{COH}}+\mathrm{O}_{2} \stackrel{k \mathrm{a}}{\longrightarrow} \mathrm{RR}^{\prime} \mathrm{C} \backslash \mathrm{OH} . \\
& \mathrm{RR}^{\prime} \mathrm{C}>\mathrm{OH} \stackrel{\mathrm{OH}}{\longrightarrow} \mathrm{RR}^{\prime} \mathrm{C}=\mathrm{O}+\mathrm{HOO} .
\end{aligned}
$$

$$
\begin{aligned}
& \mathrm{HOO} \cdot+\mathrm{RR}^{\prime} \mathrm{CHOH} \stackrel{k_{\mathrm{c}}}{\longrightarrow} \mathrm{HOOH}+\mathrm{RR}^{\prime} \mathrm{COH} \\
& \mathrm{HOO} \cdot+\cdot \mathrm{OOH} \stackrel{k_{\mathrm{d}}}{\longrightarrow} \mathrm{H}_{2} \mathrm{O}_{2}+\mathrm{O}_{2} \uparrow
\end{aligned}
$$

定常状態法により, 酸化速度 $R_{A}$ を求めると,

$$
R_{A}=R_{i}^{1 / 2} \frac{k_{\mathrm{c}}}{k_{\mathrm{d}}^{1 / 2}} \cdot\left[\mathrm{RR}^{\prime} \mathrm{CHOH}\right]
$$

となり（2）式と全く同じ形となる。実験式も酸素圧 $100 \mathrm{mmHg}$ 以上では

$$
R_{A}=K[\mathrm{BPO}]^{1 / 2}\left[\mathrm{O}_{2}\right]^{0}\left[\mathrm{RR}^{\prime} \mathrm{CHOH}\right]
$$

となり，(21）式と全く一致する。炭化水素の酸化と同じょうに ペルオキシラジカルによる水素引き抜きによる連鎖反応 (3-3') る考えられるが, 構造の考察とアルコールハイドロペルオキシド $\mathrm{RR}^{\prime} \mathrm{C} \backslash \mathrm{OH}$ OO $+\mathrm{RR}^{\prime} \mathrm{CHOH} \stackrel{k_{3}{ }^{\prime}}{\longrightarrow} \mathrm{RR}^{\prime} \mathrm{C}<\mathrm{OOH}^{\circ}+\mathrm{RR}^{\prime} \mathrm{COH}\left(3-3^{\prime}\right)$

の分解反応性とから，アルコールペルオキシラジカルは，(3-3') の方へ進まず (3-b) 式により自己分解し，連鎖担体ラジカルは HOO.であると考兄られる。反応系にアルコールヒドロペルオキ シドが存在するのは，(3-e) 式の平衡反応によって生成するもの と解釈できる。

$$
\mathrm{RR}^{\prime} \mathrm{C}=\mathrm{O}+\mathrm{HOOH} \rightleftarrows \mathrm{RR}^{\prime} \mathrm{C} \backslash \mathrm{OOH}
$$

連鎖長は炭化水素にくらべて短かいが，適当な開始反応を適用 することによって有利な過酸化水素の製造法となる。Balland, Cooper ${ }^{28)}$ は，水の共存する場合は連鎖反応とならないことを報 告しているが，連鎖担体ラジカルヒドロペルオキシラジカルが次 式のような解離平衡によって水素引き抜き反応性を减するるためで あると考えられる。

$$
\mathrm{HOO} \cdot \stackrel{\mathrm{H}_{2} \mathrm{O}}{\rightleftharpoons} \cdot \mathrm{OO}^{-}+\mathrm{H}^{+}
$$

アルコールの空気酸化は, セルロース, PVA の酸化崩壊機構 を研究するモデル实験となり，また染色物の退色機構などにも多 くの暗示をあたえるものである。アルコールラジカルの還元性 ${ }^{29)}$ は特に興味の深い問題であり，たとえばイソプロピルアルコール に二トロベンゼン，ジニトロベンゼンを加え，BPO を添加する とアルコールラジカルによる還元が起り，アニリン，フェニレン ジアミンを生成する。またこの場合酸素の存在と同じょうに BPO の誘発分解恃起らない。

\section{一文 献一}

1) J. L. Bolland, Proc. Royal Soc. A 186, 218 (1946).

2) Destillers, B. P. 626, 095

3) Shell, B. P. 708,339; F. F. Rust et al, H本特許代願公 告睢 30-9317.

4) A. V. Tobolsky, D. J. Metz, R. B. Mesrobian, J. Am. Chem. Soc. 72, 1942 (1950); L. G. Angert, A.S. Kuzminskii, J. Polymer Sci. 32, 1 (1958).

5) 川松, 高分了. 8, 643 (1959)

6) N. N. Semenov, "Some Problems in Chemical Kinetics and Reactivity". Vol. 2. p. 257, Princeton Univ. Press (1959).

7）增尼演十睢，“最近の化学とその応用”9，104（1957）。

8) 藤, 陗尼, I:化 63,748 (1960).

9) G. P. Armstrong. R. H. Hall, D. C. Quin, J.Chem. Soc. 1950, 666 Desfiller, B. P. 629, 429.

10) B. Philips, F. C. Frostick, P.S. Stracher, J. Am. Chem.

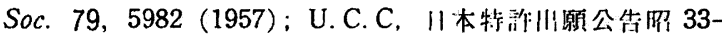
4173.

11) C. H. Bamford, M. J.S. Dewar, Proc. Royal Sof, 
A 198, 264 (1949).

12) L. Bateman, G. Gee, A. L. Morris, W. F. Watson, Disc. Faraday Soc. 10, 250 (1951).

13）増尾富士雄, 加藤真市, 有機反応機構討論会 (1958).

14）高橋, 油化協 7, 248 (1958).

15）加藤, 增尾, 化学の領域 $12,31,98,177$ (1958).

16) H. R. Cooper, H. W. Melville, J. Chem. Soc. 1951 , 1984.

17) L. Bateman, G. Gee, Trans. Faraday Soc. 47, 155 (1951).

18）下村, 日化 78, 1326 (1957).

19) C. E. H. Bawn, S. F. Mellish, Trans. Faraday Soc. 47, 1216 (1951).

20) J. W. L. Fordham, H. L. Williams, Can. J. Research B 27, 943 (1949).

21) J. L. Bolland, P. ten Have, Disc. Faraday Soc. No. 2,
252 (1947).

22) J. L. Bolland, P. ten Have, Trans. Faraday Soc. 43. 201 (1947).

23) G. S. Hammond, C.E. Boozer, C. E. Hamilton, J. N. Sen, J. Am. Chem. Soc. 77, 3238 (1955).

24）堌尾富士雄, 加藤真市, 宮坂宏保, 日化第 12 年会講演 (1959).

25) L. G. Angert, A.S. Kuzminskii, J. Polymer Sci. 32. 1 (1958).

26) M.S. Kharasch, J. L. Rowe, W.H. Urry, J. Org. Chem. 16, 905 (1951).

27) F. Mashio, S. Kato, Mem. Kyoto Tech. Univ. 5, 51 (1956) ; 6, 67 (1957).

28) J. L. Bolland, H. R. Cooper, Proc. Roy. Soc. A 225 , 405 (1954).

29）增尾富士雄，有機反応機桡討論会（1959）. 